\title{
On education in the perspective of tragedy
}

\section{KEYWORDS}

education, humanism, education philosophy, tragedy, existence, development

\begin{abstract}
Man experiences their existence constantly experiencing tension that emerges between that which is and that which could be, between the actual, known, and the unknown that barely shines in the horizon. In this uncomfortable experience, one can find potential for development, hidden behind a facade of pretence and camouflage, which, when disclosed and uncovered can be the "fuel" of satisfactory change. As a result, education can be in service of man once again. This process, as a fundamental experience, will assume the acceptance of truth about the human condition and the circumstances of its emergence in the course of life. Education not abandoning man must rediscover and re-evaluate such categories as fate, uncertainty, fragility, unforeseeability.
\end{abstract}

Adam Mickiewicz University Press, pp. 17-32

ISSN 2300-0422. DOI 10.14746/kse.2019.15.2

ORCID: https://orcid.org/0000-0002-8495-9176

ORCID: https://orcid.org/0000-0002-5238-0100

\section{Introduction}

„Progress is moving from words to experiences, from fiction to realism" Y. Congar

It seems as though there were never too few „prophets” voicing their views on how tragic the situation is in which humanity, and accordingly, the world, has found themselves. There were never too few of those who believed that it is so bad, at the same time saying that they have a wonderful antidote against all evil. They also preached that when their ideas come to life, a „miracle” will happen, we will be liberated from the darkness we were in. And it is here where those emerge that believe that this 
wonderful addition influencing the quality of the modern world is economy, and still others, to whom we are most likely closer, believing that in order to begin to act in any way, one would need to reach down to the fundamentals of humanism giving us the basic concepts of the rules of activity of man in the world. The knowledge of these rules translates into understanding of what is around us. However, one must always remember that which Janusz Korczak wrote about:

"The more one sees and the longer they live, the less certain they are of themselves. Life is great and strong, they are weak and small"1.

\section{On the practice and theory of action}

Many sensitive scientists construct tools in order for humanity not to get to "the bottom" in difficult times, sharing the fate of civilisations long gone. The establishment of foundations of human activity is among others formulating responses to periodically stated questions about the shape of knowledge, education, its humanist dimension, objective and strategy, as professor Zbigniew Kwieciński wrote, entailing finding answers to the questions:

„what and how should humanistic education be, what are its limitations over here, and what are the constitutive components enabling a chance to achieve it. Is a return to these questions reasonable... not from the standpoint of a dreamer, reformer, rebel, priest, dogma follower, madman or cold player pursuing own interests?"2

These are fundamental questions that perhaps for some may seem to mundane. However, using the words of Jose Antonio Marina, Spanish paedagogue and philosopher, which were included in his work entitled "The Failed Intelligence, or Stupidity in Theory and Practice":

„the case concerns very urgent preventive work, as stupidity is an illness that any one of us can get infected by”3 because: „Human intelligence fails if it is unable to adapt itself to reality, to understand what is happening (or what is happening with us if we are unable to solve emotional, social or political problems; if it regularly makes mistakes when it assumes absurd objectives or steadfastly remains using ineffective means; when it wastes the opportunities that arise; when it poisons our lives; when it succumbs to cruelty and violence"4.

\footnotetext{
${ }^{1}$ J. Korczak, Pedagogika żartobliwa, Warszawa 1939, p. 101.

2 Z. Kwieciński, Dylematy Inicjatywy Przebudzenia, Wrocław 2011, p. 109.

3 J. A. Marina, Porażka inteligencji czyli głupota w teorii i praktyce, Kraków 2010, p. 7.

${ }^{4}$ Ibidem, p. 9.
} 


\section{The tragedy of education, or between the inexistent past and the uncertain future}

Tragedy in human history gained strength when the education process did not fulfil the hopes laid in it, and when people started putting their „dirty fingers” where they weren't supposed to. Human intervention in everything, meaning: disturbing cycles of nature, transgressing educational reason related to experimenting by modifying all that can be modified, rejecting everything that could be linked to the experience of generations past, all of this became the daily bread. Such a condition of things brought about the paradox that uncovered the reasonability and "greatness" of all that passed. We came to realise that not long ago the majority of people:

„woke when the sun rose, went to bed when the sun set, ate home-grown meals, and worked close to home. People spoke of moments as fleeting, memories as lasting, and admonished their children with such phrases as "haste makes waste." Stories began with "Once upon a time," and we actually had a sense of what that meant. Days were based more on light than hours and years more on seasons than calendars"s.

Perhaps we need to wait until a lot of time has passed in order to then long for what is gone to save what still can be saved. Such nostalgia is most probably an educational experience that every man had experienced, experiences or will experience. As we can read in the Different dictionary of the Polish language (Inny słownik jezzyk polskiego)" published in 2000 by the PWN publishing house and edited by M. Bańko, nostalgia is a very valuable feeling of regret due to the loss of something or the unavailability of the world past ${ }^{6}$. Nostalgia seems to be a natural instinct against what is imposing, what pretends to be certain. As Hegel once noted, perhaps one should rather wait until that which is aggressive, intense, persistently intrusive and loud comes to pass, indeed:

„When philosophy paints its grey in grey, one form of life has become old, and by means of grey it cannot be rejuvenated, but only known. The owl of Minerva takes its flight only when the shades of night are gathering.".

${ }^{5}$ J. Naisbitt, N. Naisbitt, D. Philips, High Tech. High Touch, Nicholas Brealey Publishing, London, 2001, p. 32.

${ }^{6}$ Conf. M. Bańko, (ed.), Inny słownik języka polskiego, Warszawa 2000.

7 G.W.F. Hegel, Elements of the Philosophy of Right, transl. by T. M. Knox, 1952, from Wikiquote: https://en.wikiquote.org/wiki/Georg_Wilhelm_Friedrich_Hegel\#Elements_of_the_Philosophy_of_Right_(1820). 
One would love to say, however, that man is not an owl, active when the day is gone. Most probably the owl does not experience longing for that what was, but a "longing” for activity. We, people, however, at least a part of us, do not hold longing to be alien. Perhaps there could be people around us, for whom longing for that which was is something alien, an abhorrent feeling that must be avoided and shamed. However, many people understand that it is a feeling that cannot be let go, as the lack of reflection on what we left behind can bring about unforeseeable consequences upon us. Most probably, however, one could also find a large group of people who will mock us that we are not modern enough, or we will just be referred to as weirdos or madmen, heretics or plainly romantic idiots, only longing for that which is gone. The latter are favoured by a biblical quote on the relation with that which is no more, in that man should:

"Let the dead bury their dead".

However, anybody who acquired at least a little bit of humanist knowledge will respond that this is tragedy of those dead in spirit. The case concerns those who do not see the inner strength, the inspiration, they lack internal motives to undertake any actions or a little bit of unquestioning pride of the achievements or the output of ancestors. Indeed, M. Scheler noted:

„The cradle of tragedy - the art, in which it may arise - are not exclusively relations between values nor the relations between cause and effect or the forces that destroy them, but the particular relation between the relations of value and the relations of causality"

Hence, one must go back to the past that actually bears within itself the educational power of inspiration, to these valuable experiences that have in the past fruited with their own, valuable solutions. However, one must remember that one cannot face the challenges of a new era proclaiming the illusionary return to historic behaviour patterns, but one must really reestablish the condition of the prior era and, for instance, in the words of prof. Aleksander Nalaskowski, treat:

„oneself seriously, irrespective of what Europe might think about it”10.

${ }^{8}$ King James Bible, Luke 9, 60.

9 M. Scheler, O zjawisku tragiczności, (w:) Arystoteles, D. Hume, M.Scheler, O tragedii i tragiczności, Kraków 1976, pp. 51-75 [retranslated into English by the translator of the present paper into English].

10 A. Nalaskowski, Edukacyjny show, Kraków 1998, p. 11. 


\section{Tragedy, or education as a „Gordian knot"}

An interesting and significant term category has emerged here that may serve as a component significant for our reflection concerning education in the concept of contemporaneity, that is: tragic, or tragedy. For instance, what will the Polish literary concept dictionary tell us about tragedy? Well, tragedy is:

„the unsolvable conflict between values and necessities determining the life of a hero devoid of the possibility of making any advantageous choice for themselves between them. Indeed, all actions shall lead them to the same unavoidable catastrophe: death or ultimate life failure. The hero themselves - unconsciously or consciously - brings upon themselves peril and, irrespective of the force of character, the tension of feeling and will, uniqueness of their deeds and virtue of their intentions, they also become the victim and the perpetrator. The futility of their actions is determined either by higher forces governing the human world, fate, destiny, doom, God's will, blind laws of nature, or by oppositions between moral, social and historic rights that are equally independent of them (...) Tragedy can shine in several literary forms, but its domain is primarily tragedy in the area, where it is the key rule of construction of the fate of the hero, and the fundamental factor shaping reactions and experiences of the recipient. Due to the aesthetic, among others, effect of tragedy, in particular cooperating with pathos, it is considered to be one of the aesthetic categories"11.

The above description of a literary phenomenon, not requiring modification, shows the situation of education in many "modern countries”, which assuming a similar perspective had concluded that its constitutive component shall become the condition of the unresolvable conflict between the values and the necessities that determine life.

And actually, analysing contemporary education systems in the world, one could get such a notion. But we aim for education that gives rise to an elevation above intellectual mediocrity characteristic of primitive individuals subordinate to their own instinct of self-preservation. We seek education that will reduce to a minimum the plane, where the above described unresolvable conflict between values and necessities determining human life shall be reduced to a minimum.

\section{Educational scepticism as part of everyday tragedy}

No period of history, and even more so, no period of history from the perspective of what transpired, the achievements of science, can be summarised in one simplified system or diagram. Every period of history contains within itself diverse, fre-

${ }^{11}$ J. Sławiński (ed.), Słownik terminów literackich, Wrocław 1976 p. 467 
quently opposing streams and tendencies, various less or better crystallised ideals, diverse visions of the future. Any one of the most frequently emerging notions in history is believed to be the best representation of a specific period, however, not infrequently these dominant streams stem from the ignorance of their supporters. The result of this is the emergence of fundamentally different opinions on the past or on the educational process of creation of the image of contemporaneity and the future. Hence, we cannot imagine achieving anything in the world of man without comparing that which is and that which is to be with that which was. However, as one of the most interesting contemporary thinkers, Amin Maalouf, a Lebanese writer, philosopher, anthropologist and ethnologist living in France since 1976, a Christian with Arab roots, chosen member of the Académie française in the year 2011, replacing the deceased Claude Lévi-Strauss, put it:

„historical civilisations have achieved the end of their development; that they experience moral bankruptcy, similarly anyway to all other individual civilisations that divide mankind"12.

The case concerns, among others, the view preaching the end of development of humanity that stems from its powerlessness in the context of the scenario of everyday reality that was written and that is implemented by it. In this scenario, tragedy seems to describe the facts of our day, meaning - the uncertainty or bankruptcy of all of humanity's resources overhanging the world.

Indeed, perhaps today we do not share the sometimes naive optimism of our 'romantic' predecessors, as we are more sceptical, and, to our peril, we look to the past ever less frequently, as we fear stumbling over the present that fleets so quickly. As a result, we often make doors that in the future would have remained wide open. Hence, many people experience particular enlightenment, in course of which they are ready to accept many historic statements literally, believing that this was the output of modern times. And so, the same ideas continue to emerge over and over again that we describe as the characteristic properties of our time. In this manner, components continue to return such as, among others ${ }^{13}$ : perception of the subject, the rule of unhindered development of freedom, the uncovering of truth as inevitable lie or the negation of the tradition of rationalism.

What do we need to unconditionally remember, then?

12 A. Maalouf, Rozregulowany świat, Warszawa 2011, p. 22 [retranslated into English by the translator of the present paper into English].

${ }^{13}$ See Bogdan Barn, Postmodernizm, Kraków 1992, p. 57. 
First of all, the „rule of subjectiveness” returning like a boomerang in the writings of contemporary scientists - cogito, ergo sum - as pointed out by Descartes, who preached all around that he lets go of worthless tradition pronouncing the priority of will over everything else. Second of all, we cannot forget the rule of unhindered development of subjective freedom, which as a consequence leads to Hegel's finality of the Absolute Spirit, being beauty incarnate, meaning, the synthesis of reality with thought, form with content, or idea with phenomenon.

And a note for those who would term themselves humanists. We are still left with critique of rationalism (e. g. like Husserl's), under the banner of „back to things", leading to the fusion of the mind with the experience. As J. Tischner wrote:

„the point was for the mind, as rationality - to be able to pick the means to fit the ends, but also - as a rule of wisdom - for it to be able to set the objectives of man"14.

This image of recurring components is a great simplification. The perspective that appeared before us is the tragedy of the abandoned man in society, the tragedy of their ignorance, the tragedy of ambiguity, the tragedy of the multitude of existing solutions, with a simultaneous reduction, necessity to choose, lack of clear answers to the questions that have been put forward, inability to pick means on the way to one's goal. Thanks to these properties human existence seems to be "genetically" burdened by tragedy or tragic. Were we, however, to domesticate the above presented perspective of understanding of the thought category that is "tragedy", and to put it to harness it to do useful educational work, it could appear that, as Aristotle put it, the objective of educational tragedy understood as such would have been:

„the awakening of the feelings of fear and mercy to bring about blissful liberation for those feelings"15.

In this context, tragedy appears as a space of creative inspiration stemming from the level of emotional sensitivity built on top of the mind. And all this to dominate over nature.

${ }^{14}$ J. Tischner, Katolicyzm a Nowoczesny Świat, Krakw 1995, p. 15 [in:] U. Altermatt, Katolicyzm a Nowoczesny Świat, Kraków 1995.

${ }_{15}$ W. Tatarkiewicz (ed.) - Arystoteles, David Hume, Max Scheler. O tragedii i tragiczności, Kraków 1976, p. 8. 


\section{Educational tragedy as a consequence of the pessimism embedded in existence}

Pessimism in the context of the of the conceptual category of "tragedy" can be sought in the writings of contemporary thinkers. Władysław Tatarkiewicz noticed this concept of tragedy, when he wrote:

„In life, fate can sometimes be as tragic as it is for Oedipus or Phaedra on the stage. We are talking about actual people that found themselves in tragic circumstances. Anyone who would ask what it means can be told: these people have found themselves in a position without a way out. More precisely: without a good way out. This exactly is a tragic situation"16.

However, certain commonalities can be found between these very different perspectives of understanding of tragedy. Events are intertwined into the human existence that are constitutive of it and that cannot be foreseen. They break meticulously woven plans and objectives. They put man in a situation of complete „uncovering”, and, hence, helplessness. It is impossible to "play” someone else with respect to them. They are the deepest experience during which, the sole thing that remains is to face them engaging all one's possible power (values). So, hence, this is not a perspective „without a way out”, even though this approach may be related to the the relentlessly emerging "unpredictability” of what awaits us. The paedagogy of experience, in the sense of discovering that which we do not know, that which is unpredictable, and what we must cope with, is a perspective that renowned Polish sociologist J. Szczepański wrote about:

„(...) unforeseen possibilities, such as placing man in the presence of forces, phenomena to which man is exposed and with which man has to cope, on which they have no influence, which are completely independent of them and which aren't necessarily written in one's genes and the social structures, in the nature of the order of culture. It was fate as a trial of one's value, of their power, when one is exposed to trials that they cannot influence and the existence of which they were not aware about until they suddenly came to light as an evil force"17.

\section{The education perspective - fear and being"}

Tragedy such as face expose the phenomenon described as katharsis. The situation of being stripped from pretence and pretend lives establishes - paradoxically - the

\footnotetext{
16 W. Tatarkiewicz, Parerga, Warszawa 1976, p. 122.

17 J. Szczepański, Sprawy ludzkie, Warszawa 1984, p. 322.
} 
possibility of the deepest possible experience of oneself. The experience of tragedy in situations of dominance of fate uncovers the weakness of perception of man as in total control of their life. The visions of a "no problem” person who is happy, carefree, going trough life "like a torpedo” are turned to dust. Tragedy discloses the complexity of human existence, constantly exposed to the influence of forces independent of it, having at the same time the power to make radical changes. Nikolai Berdyaev goes so far as to believe that it is specifically these unforeseen events in which we experience tragedy and dilemma that have the most importance as they expose the human condition fully

\begin{abstract}
„(..) in one's existence, the most important is fate bringing with itself pain, the antinomious fusion of freedom and fate, the irreversibility of fate (...). A person is a living opposition, an opposition between the personal and social, between form and content, between finiteness and infinity, between freedom and fate. For this reason, a person cannot be considered completed, it is not given as an item, but created, they create themselves, are dynamic (...). When changing, a person still remains the same as well, is identical to themselves, is true to themselves. Such a connection of changes and permanence, persistent novelty and identity comes most strongly to shine in the awareness of one's destiny and fate (...)"18.
\end{abstract}

In „The Unbearable Lightness of Being”, Milan Kundera expresses their astonishment at the „incomplete closure” of man and the related experience of tragedy. In a world that loves procedures, standards, set pattens of success, for uncertainty to be considered true cannot be acknowledged. The consciousness of singularity of life in concert with the observation of proof of its passing makes life exposed to the experience of its irreversible loss.

„We can never know what to want, because, living only one life, we can neither compare it with our previous lives... a sketch for nothing"19.

Such existential tragedy, being an educational platform, sometimes reminds us of the dance of the straw-wrap dance, in which the unreduced problem of the choice of the partner emerges, between political connections and the will to cross this enchanted circle, through the acquisition of ideas contained in the intellectual heritage of mankind.

18 M. Bierdiajew, Rozważania o egzystencji, Warszawa 2002, p. 95 [Truth and Revelation; retranslated into English by the translator of the present paper into English].

19 M. Kundera, The Unbearable Lightness of Being, Harper Perennial Modern Classics, 2009, p. 5. 


\section{Tragedy politicised, or on educational intertwining}

Tragedy as a politicised conceptual category can be found, among others, in Hannah Arendt, who indicates the chasm that emerged in Western culture in about the 4 th century BC in Greece. At that time it seemed that, politically, society is standing at a chasm. It was the chasm that emerged between thinking and action. As Hannah Arendt put it:

„In truth, intellectual activity not constituting mere counting of resources for assumed or desired objectives but caring, in the general sense, about the sense, started playing the role of "reflection”, or something that emerges only when activity had already decided on the shape and character of reality. Action in itself, in turn, was banished to remain in the senseless realm of accident and blind fate"20

An interesting educational perspective that Arendt noted is the one, where thinking is secondary, preceded by activity, and only applies to those actions related to drawing up a balance of the damage that had arisen.

As Hannah Arendt stresses, tragedy is also the moment, when the moment Socrates dies as a result of catastrophe due to the weakness of persuasion he used with respect to the judge and his friends, Plato lost the faith in the views he preached earlier. This refers to the convictions that applied to polis and the basics of the concept of truth that he constructed, and for which he found no alternative, acceptable view ${ }^{21}$. This tragedy of the situation, in which the philosopher found himself, is the „tragedy of hopeless alternatives" 22 . Hence, substantiated may seem the attitude represented by Jose Ortega y Gasset, in his work „Por qué se vuelve a la filosofía” [Why return to philosophy?], here he wrote, among others:

„a given period is a collection of positive and negative tendencies; a quick wit and the ability to plan ahead walk hand in hand with stupidity and blindness. The period is characterised not only by the desire of certain things, but also decisive dislike of others"23.

One could risk saying that this dislike is related to the awareness of, among others: temporariness, departure of certain ideas together with a specific genera-

${ }^{20}$ H. Arendt, Polityka jako obietnica, Warszawa 2005, p. 40 [translated into English by the translator of the present paper into English].

${ }^{21}$ Ibidem, p. 41.

22 The phrase „tragedy of hopeless alternatives” was popularised by Marian Brandys.

${ }^{23}$ Jose Ortega y Gasset, Po co wracamy do filozofii, Warszawa 1992, p. 95 [translated into English by the translator of the present paper into English]. 
tion that carries them, incidentality of circumstances facilitating their emergence, finally - the tragedy of the situation that constantly requires making choices ${ }^{24}$. These situations describe the paths of human „intertwining”. In this manner, the next generation refers to those departing as victims of their time. Oe could quite Z. Kwieciński here, that, for instance, in the Polish situation:

„we are ... dealing with people of different orientations, the pre-modern and the post-modern, the waiting and the active representing the old order from before the Transformation of 1989 (with employment for everyone, social security and religious refuge) and the new order, with democracy, the free market, private ownership and tolerance as its pillars"25.

Intertwining or dependence are phenomena that have their internal as well as external educational values. On the one hand, they touch directly upon certain individuals, on the other hand, indirectly, they touch upon the environment and observers - spectators. These phenomena seem to a certain extent to be a natural consequence of the evolving world. Amin Maalouf, a Lebanese writer, philosopher, anthropologist and ethnologist living in France since 1976, a Christian with Arab roots, chosen member of the Académie française in the year 2011, replacing the deceased Claude Lévi-Strauss, noted:

„Both yes and no. The fact that human communities, unavoidably, but conflicts as well, become ever more open, is significantly a normal result of the development of the phenomenon of communication. And the fact in turn that we may deplore, what we should banish, is that this technological progress is not accompanied by heightened awareness enabling the protection of humanity banished against its will in the maelstrom of history"26.

This gives rise to a question. Whether a "tragedy” may be treated only as an educational phenomenon or a set of predetermined events, „belonging” only to specific individuals or social groups? Such treatment of the phenomenon of tragedy would lead to the reduction of the multidimensional phenomenon of education to specific cases. Hence, one would love to say that nobody is exclusively permitted to treat their experience as exclusive, as their actions stem from functioning within a community that is the co-creator of the entire context.

${ }^{24}$ Conf. M. Janion, Czyn i klęska. Rzecz o tragizmie [in:] M. Janion, Gorączka romantyczna, Warszawa 1975

${ }^{25}$ Z. Kwieciński, Nieuniknione? Funkcje alfabetyzacji w dorosłości, Toruń - Olsztyn 2002, p. 74.

26 A. Maalouf, Rozregulowany świat, Warszawa 2011, p. 57 [retranslated into English by the translator of the present paper into English]. 


\section{The educational turn towards the original experience}

As we look on the phenomenon of education as the celebration of the mystery of knowledge, based on dialogue between the educator-guide and the choir, there emerges a fusion of this dimension with tragedy of the antiquity, which was composed of the following stages that follow each other: the prologue, the parode, the episode, the stasimon, the kommos and the exode. In this context, tragedy becomes for us a model of initiation, understood as a gateway through which the chosen enter the "interior of the world", the world of education constituting the core of humanity. There is only one difference in that the Greek tragedy ends in catastrophe. Thanks to the listing in the table below, it is easier to see the mechanisms and rules characterising the individual stages of tragedy.

Table. Diagram of the antique tragedy from the point of view of its educational rules

\begin{tabular}{|l|l|l|}
\hline Stages of the tragedy & \multicolumn{1}{|c|}{ Educational scenario } & \multicolumn{1}{|c|}{ Tragedy educational rules } \\
\hline Prologue & $\begin{array}{l}\text { Appearance of a guide announcing the } \\
\text { topic }\end{array}$ & $\begin{array}{l}\text { Rule of decorum - responsibility for } \\
\text { content and form }\end{array}$ \\
\hline Parodos/ Parode & Appearance of the choir, with songs & $\begin{array}{l}\text { Rule of unity - of the time, of the place, } \\
\text { of the events - specific number of ac- } \\
\text { tors (no group scenes, individualisation }\end{array}$ \\
\hline Episode & $\begin{array}{l}\text { Development of events - acting by } \\
\text { actors }\end{array}$ & $\begin{array}{l}\text { Rule of necessity - Emergence of con- } \\
\text { flict }\end{array}$ \\
\hline Stasimon & $\begin{array}{l}\text { Appearance of the choir } \\
\text { Rule of mimesis - recreation (reflec- } \\
\text { tion of reality) }\end{array}$ \\
\hline Kommos & Lament of the individual & Rule of arrangement in order \\
\hline Exode & $\begin{array}{l}\text { Ultimate song of the choir, exit from } \\
\text { the stage }\end{array}$ & Rule of comparison, summary \\
\hline
\end{tabular}

Source: Own work

Tragedy in this area was an action fusing sensual experiences with intellectual reflection on them. In this ancient action, there can be observed the construction of a single image of knowledge. This was also noted by literature Nobel Prize laureate of 1946 Herman Hesse, who wrote:

"It is felt by all children, but not by all with the same intensity and subtlety, and in many this vanishes as they take in the first letters of the alphabet. Others retain the mystery of childhood for a long time, and the traces and echoes remain in them until the days of grey hair and old age"27

27 H. Hesse, Iris i inne opowiadania inicjacyjne, Kraków 1991, p. 10. 
The significance of experience became the basis for the formulation of one of the main cognitive directives of the scientific world, by Martin Heidegger, who believed that „in order to get to know, one must let be" 28 . What does it mean for the educator „to let be"? And using at this stage a different, renowned German philosopher, Max Scheler, let us attempt to respond to the question put forward as follows: "to let be" means to acknowledge, accept that the sheer existence of another that is a value functioning within the scope of the freedom due to them. It seems that the paedagogical rule of „letting be”, would includes the conceptual category of "tolerance” in its original meaning, very often omitted. Tolerance stems from the Latin word tolerantia "patient endurance”; and the Latin verb tolerare - „to endure”, „suffer in pain”. Endure, meaning, to accept one's powerlessness to change the world as one would see fit, or to tame one's egotism, negotiating it, and with a different egotism that functions within the reasonable freedom that is due to it, and, hence, banishing both egotisms to forced coexistence, forced limitation.

What of this „being” then, if man is limited in the space of freedom that is their right? Can such an individual „be”? Antoni Kępiński, renowned medical doctor and humanist, known, among others, as the creator of the concept of axiological psychiatry, researching former concentration camp prisoners noticed in their behaviour a certain significant rule, valuable in particular for contemporary paedagogical theory, stemming from the fact that:

„the biological imperative is exceedingly strong, and much effort must be put into not thinking only about bread when one is hungry, about water when one is thirsty, or the painful spot, when one feels pain. This effort, however, was necessary to maintain inner freedom - a free space where one can freely think, dream, plan, make decisions, release oneself from the nightmare of the present. If prison life, this anus mundi saw as much devotion, then specifically thanks to inner freedom"29.

This inner freedom that prof. Kępiński thought about, is the autonomy of the mature individual, the mature „I”, or the ability to shape in the educational process, to refer, through a mature, competence-developed sensitivity, to a different "I”. Such attitudes towards paedagogy fir instance as a particular competence sensitivity, can be found in the scientific work of, among others, prof. Zbigniew Kwieciński, the creator of the Polish school of education sociology, who defines education as:

\footnotetext{
${ }^{28}$ See. M. Heidegger, Bycie i Czas, Warszawa 2008.

29 A. Kępiński, Rytm życia, Warszawa 1972, p. 3.
} 
„the sum total of influences upon an individual and groups, facilitating such development that to the greatest extent they would become aware and creative members of the social, cultural and national community, and that they would haven the ability of active self-realisation of their own identity and of development of their own I by taking supra-personal tasks, through the maintenance of own continuity in course of fulfilment of tasks removed in time" ${ }^{30}$.

\section{Conclusion}

In the logic that shapes education systems in the world, a common rule can be found. This common rule is the rejection of all that seems not needed or unnecessary in the activity strategy of state policy. Many educational visionaries even announced the end of paedagogy as a science. One of these was Ricardo Massa, a former and already deceased head of the Institute of Paedagogy at the Faculty of Humanities of the University of Milan in Italy.

"The end of paedagogy, with certainty, but also the inability of philosophy, didactics and education sciences to become aware of this, hence, to fulfil the task of replacing it, to effectively contribute to the solution of theoretical and practical problems of education. A space opens up here in the broad field of discourse and everyday practice against teaching and education, to non-fictional and clear transformation of paedagogy. It is a space for new paedagogy as the "clinic of education” aimed at finding the symbolic and material structure of the educational experience, in opposition to the deceit of all identification of the area of paedagogy with philosophy, the theory of vocational education or adulthood, experimental research or a specific epistemology, all of which was again suggested in a course of consideration. To achieve this, however, at least three other questions must be taken on (in paedagogy), the failure to acknowledge which meant the end of its own image in contemporary culture. What is the place, what is the public and, hence, what is the language of the new capacities of paedagogy?"31.

Education seems to force diverse artificial, unnatural reactions from its recipients, bringing its activity solely down to the aesthetisation of the world, hence, stripping the listeners from the ability to react on their own to that which is happening around them. Two educational dimensions of aesthetisation summarise our musings on tragedy. This means sterilisation and particularisation. The first approach to the educational space containing specific content or message form are related to the "purification" of common beliefs, where the omnipresent mechanism is the overgrowth of form over content, causing education to be pushed [aside] to a „pop” form.

30 Z. Kwieciński, Edukacja jako wartość odzyskiwana wspólnie. Edukacja 1991, no. 1, p. 89.

31 R. Massa (ed.) La fine della pedagogia cultura contemporanea, Unicopli Milano 1988, p. 199. 
The second model of educational aesthetisation in turn is characterised by a demand approach to exclusivity of content and methods. In this particularisational approach, the quite weak method of scientifisation and indication of unique scientific values is used, with these values useful only to those who present them.

The aesthetisational tragedy of education

\begin{tabular}{|l|l|l|}
\hline $\begin{array}{c}\text { TYPES OF EDUCATION } \\
\text { AESTHETISATION }\end{array}$ & \multicolumn{1}{|c|}{ TYPICAL BEHAVIOUR } & \multicolumn{1}{|c|}{ RESULTS } \\
\hline STERILISATION & $\begin{array}{l}\text { "Purification” of common beliefs } \\
\text { (Form over function, push towards } \\
\text { a „pop” form } \\
\text { „Via non-specialised, commonly } \\
\text { available, modes of communica- } \\
\text { tion” }\end{array}$ & $\begin{array}{l}\text { UOPULISM” } \\
\text { PURNING INTO KITSCH }\end{array}$ \\
\hline PARTICULARISATION & $\begin{array}{l}\text { Stripping „concepts" of COM- } \\
\text { MON ACCESS to them - COM- }\end{array}$ & $\begin{array}{l}\text { USURPATION - (takeover) } \\
\text { Claiming exclusivity through } \\
\text { scientification and indication of } \\
\text { unique scientific values }\end{array}$ \\
\hline
\end{tabular}

Source: Own work

Hence the emerging need to look at education as a plane of creating of the spirit of internal freedom, as Kazimierz Dąbrowski, psychologist, psychiatrist, philosopher and paedagogue, creator of the theory of positive disintegration, wrote, which becomes the basis of the process of upbringing, with no place left for creating, of reining and almost omnipotently violent competition in contemporary society, where:

„lies and primitive egotism are officially accepted in politics, in course of creation of extensive yet clear for insightful people facades of justice for the masses who have no time and no power of intelligence to become aware of these issues due to their nearsightedness, and nearsightedness based on the achievement of their own, limited interests". ${ }^{32}$

Hence, the educational situation described by us as „letting be”, being the result of work of paedagogues as part of competence sensitivity, then using inspiration that may be provided by the scientific theory developed by Kazimierz Dąbrowski, is the synthesis of individual properties of an individual, their talents and feelings as well as of the social properties of the individual that are, among others, autonomy, empathy or responsibility. Dąbrowski himself described these two planes as the individual

32 K. Dąbrowski, Moralność w polityce. Wielopoziomowość funkcji uczuciowych i popędowych w życiu społecznym i politycznym oraz w instytucjach („bis”), Warszawa 1991, p. 18. 
essence and the social essence. Hence, competence sensitivity itself, will be a struggle towards a specific, empirical idea of society. Dąbrowski believed that the consequence of disappearance of the essence will be worse than death or non-existence.

\section{Bibliography}

Altermatt U., Katolicyzm a Nowoczesny Świat, Kraków 1995

Bańko M. (ed.), Inny słownik języka polskiego, Warszawa 2000

Barn B., Postmodernizm, Kraków 1992

Bauman Z., Nowoczesność i zagłada, Warszawa 1992

Bielik - Robson A., Kłopoty z przyjemnością. O tak zwanym kryzysie wartości w świecie konsumpcyjnym, Tygodnik Powszechny 1997, no. 42

Bierdiajew M., Rozważania o egzystencji, Warszawa 2002

Dąbrowski K., Moralność w polityce. Wielopoziomowość funkcji uczuciowych i popędowych w życiu społecznym i politycznym oraz w instytucjach („bis”), Warszawa 1991,

Gasset J. O., Po co wracamy do filozofii, Warszawa 1992

Heidegger M., Bycie i Czas, Warszawa 2008.

Hesse H., Iris i inne opowiadania inicjacyjne, Kraków 1991

Horkcheimer M., Adorno T., Dialektik der Aufklärung, Frankfurt 1989.

Janion M., Czyn i klęska. Rzecz o tragizmie [in:] M. Janion, Gorączka romantyczna, Warszawa 1975.

Kępiński A., Rytm życia, Warszawa 1972, p. 3.

Kwieciński Z., Edukacja jako wartość odzyskiwana wspólnie. Edukacja 1991, no. 1, p. 89.

Kwieciński Z., Nieuniknione? Funkcje alfabetyzacji w dorosłości, Torun - Olsztyn 2002

Kundera M., The Unbearable Lightness of Being, Harper Perennial Modern Classics, 2009.

Marina J. A., Porażka inteligencji czyli głupota w teorii i praktyce, Kraków 2010

Massa R., ed.) La fine della pedagogia cultura contemporanea, Unicopli Milano 1988

Nalaskowski A., Edukacyjny show, Kraków 1998.

Nietzsche F., O prawdzie i kłamstwie w pozamoralnym sensie, [in:] Pisma pozostałe 1862-1875, Kraków 2004

Scheler M., O zjawisku tragiczności, [in:] Arystoteles, D. Hume, M. Scheler, O tragedii i tragiczności, Kraków 1976.

Sławiński J. (ed.), Słownik terminów literackich, Wrocław 1976 p. 467

Sugiera M. (ed.), W stronę rytuału. Od Yeatsa do Węgajt, Kraków 1999

Szczepański J., Sprawy ludzkie, Warszawa 1984

Tatarkiewicz W., Parerga, Warszawa 1976

Tatarkiewicz W., (ed.) - Arystoteles, David Hume, Max Scheler. O tragedii i tragiczności, Kraków 1976, p. 8

The King James Bible, available online at www.kingjamesbibleonline.org.

Witkowski L., Śmiech jako opór i wyzwolenie (pogranicze wiedzy, wiary i władzy) [in:] Z. Kwieciński (ed.), Nieobecne dyskursy, part 1, pp. 94-95

Witkowski L., Uniwersalizm pogranicza. O semiotyce kultury Michała Bachtina w kontekście edukacji, Toruń 2000 